\title{
El origen de la Mesa Maestral en la Orden de Santiago*
}

\section{The origin of the Masters Bureau in the Order of Santiago}

\author{
MANuel LóPez FeRnÁNDEZ**
}

\begin{abstract}
RESUMEN
En las páginas siguientes tratamos de analizar las circunstancias que originaron el nacimiento de la Mesa Maestral en la Orden de Santiago, así como las consecuencias inmediatas que la aparición de este organismo económico -fuente exclusiva de rentas para los maestres- tuvo en dicha Orden. El análisis lo hacemos apoyándonos en el documento correspondiente al Capítulo

General donde se estableció un nuevo rumbo para el reparto de los bienes temporales de la institución santiaguista. $A$ pesar de que dicho documento está sin datar, nuestra opinión es que corresponde

al Capítulo General de 1271 y que la

Mesa Maestral surgió en el seno de la Orden de Santiago como consecuencia de la presión que los comendadores ejercieron sobre el maestre Pelay Pérez

Correa en los años finales de su vida.
\end{abstract}

ABSTRACT

In the following pages we try to analyze the circumstances that led to the birth of the Masters Bureau in the Order of Santiago, as well as the immediate effects that the birth of this economic body, exclusive source of revenue for the Masters, was in that Order. The analysis we do to build on the document for the General Chapter, which set a new course for the temporary sharing out of property in the santiaguista. institution Although the document is not dated, our view is that belongs to the General Chapter of 1271 and that the Masters Bureau arose within the Order of Santiago as a result of the pressure exerted by the Knight commanders on the grand master Pelayo Perez Correa in the final years of his life.

\section{PALABRAS CLAVE}

Orden de Santiago, Capítulo General, Pelay Pérez Correa, Mesa Maestral

\section{KEY WORDS}

Order of Santiago, General Chapter, Pelay Perez Correa, Masters Bureau

* Fecha de recepción del artículo: 2009-09-18. Fecha de aceptación del artículo: 2009-10-23.

** UNED (C.A. Campo de Gibraltar). C.e.: lopezfernandezm49@ hotmail.com. 


\section{A MODO DE INTRODUCCIÓN}

El estudio que aquí presentamos tiene un doble objetivo: aportar nuevos datos documentales a los hasta ahora publicados sobre el origen de la Mesa Maestral en el seno de la Orden de Santiago y, apoyándonos en la suma de todos ellos, defender nuestra postura de que dicha entidad económica surgió en el Capítulo General de 1271 como consecuencia directa de la presión de los comendadores sobre el entonces maestre de la Orden, Pelay Pérez Correa ${ }^{1}$.

Somos conscientes de que en el desarrollo del tema objeto de estudio podíamos haber adoptado una estructura formal en la que se resaltaran aspectos tales como los objetivos antes señalados, la situación de la Orden previa al momento histórico en que nos centramos, un análisis de las fuentes documentales en las que se apoya el trabajo, y finalizar con una exposición de los cambios que se producen como consecuencia de la aplicación de los establecimientos en los que surge la Mesa Maestral. No obstante, siguiendo una directriz menos ortodoxa y sin marginar los aspectos que acabamos de reseñar, preferimos comenzar esa tarea realzando la importancia del documento que aportamos en el apéndice de este artículo, verdadera acta de nacimiento de la Mesa Maestral en la Orden de Santiago².

No por otra razón hemos tratado primero de acercarnos a la insegura datación del mencionado documento, y luego profundizar en aspectos internos del mismo para tener una visión general de las circunstancia internas que vivieron los santiaguistas con anterioridad al Capítulo General de 1271, donde se tomaron importantes decisiones que afectaron a la administración de los bienes temporales de la Orden. Conocidos esos aspectos, hemos entroncado luego con la otra directriz antes señalada, exponiendo las consecuencias que tuvo para la Orden, tanto a corto como a largo plazo, la aparición de la Mesa Maestral.

\section{UN DOCUMENTO DE DIFÍCIL DATACIÓN}

El documento que tratamos de datar corresponde a uno de los establecimientos $^{3}$ que contiene el manuscrito 8.582 de la Biblioteca Nacional de Madrid ${ }^{4}$. Ya dijo Eloy Benito Ruano, en un interesante trabajo sobre este manuscrito ${ }^{5}$, que la tras-

1 Algunos de los datos aquí aportados han sido entresacados de nuestra tesis doctoral, publicada con el título La Orden de Santiago y el maestre Pelay Pérez Correa. Ciudad Real. Instituto de Estudios Manchegos, 2007.

2 Este documento ha sido publicado por JOSSERAND, Philippe: Église et pouvoir dans la Péninsule Ibérique. Les Ordres Militaires dans le Royaume de Castille (1252-1369). Madrid, 2004. También aparece publicado en nuestra tesis doctoral: La Orden de Santiago y el maestre Pelay Pérez Correa. Instituto de Estudios Manchegos. Ciudad Real, 2007.

3 Como es sabido, los diferentes decretos de los Capítulos Generales solían comenzar con la palabra «establecemos»; de aquí el término establecimiento aplicado al conjunto de esos decretos.

4 En adelante nos referiremos a este manuscrito como (BN. Ms. 8.582 )

5 Véase: «Establecimientos de la Orden de Santiago durante el maestrazgo de D. Pelay Pérez Correa». Homenaje a Juan Regla Campistol. Valencia, 1975, tomo n. ${ }^{\circ}$ 1, pp. 93-101. 
- El comendadoz maṽoz de anagor dongazri qounez racle comeridador mayor de portotral don' cfeulan Pernardez 2 los treze del feino deleon pero inusg comendador de mezrda $/ 2$ fez natro pezez comendadoz de trepar a a azi gio ariays comi de mote molin a del Eeyno de caftill a pero fernandes taleyzos counz de monte fernando $p$ Son nuro ₹c3 comendagor detolejo 2 Jon garn pezez comz" do beles 2 slfoufobordatto comendador de fan. tagio de insents

OS Jon pelay pezez por La gta de dios maeftre

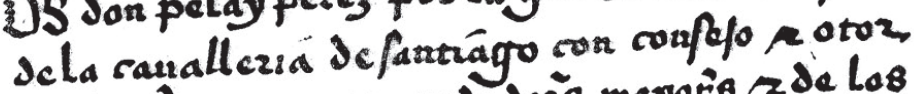

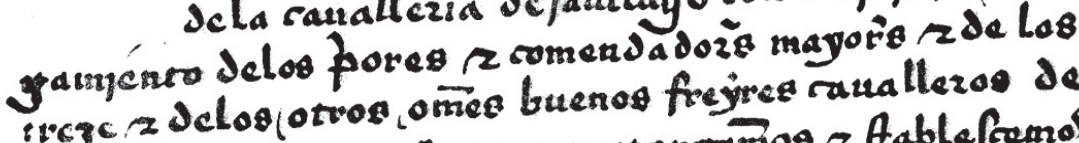

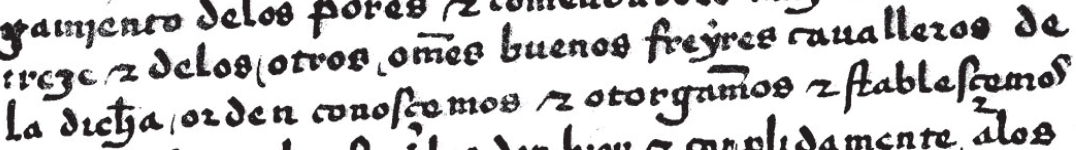

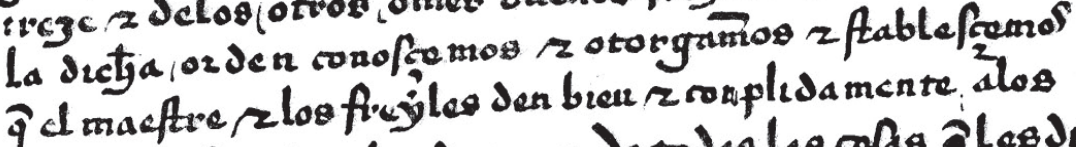
gilos

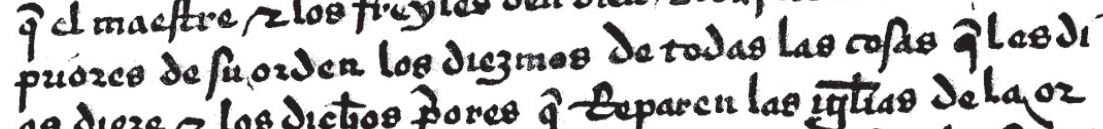

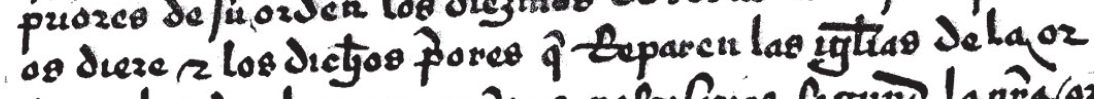

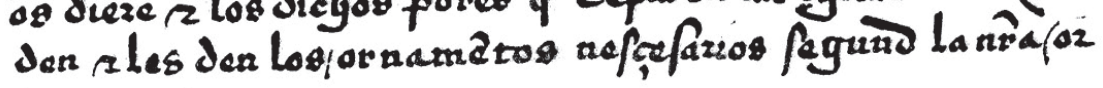
dern manda.

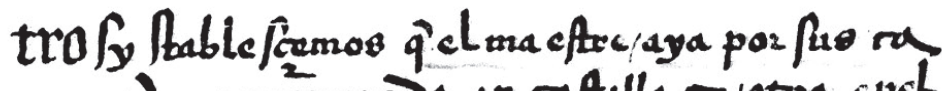

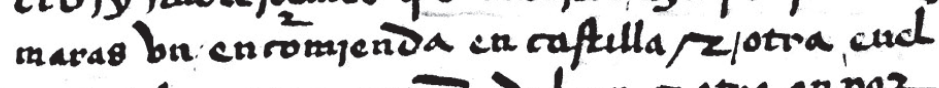

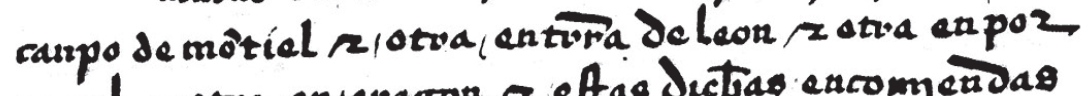
togal $z$ otta, en/awagon $z$ eftas ductyas encom eños tengau freỳzss por el queden nenta delas Bentas de icllas, 2 a proucan ol os figyzes delos conbentos a los

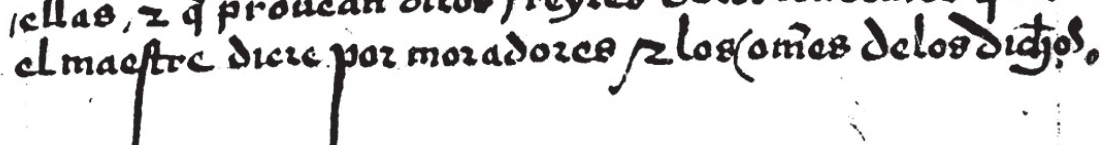

Figura 1. Fotocopia del folio 45r. del Manuscrito 8.582 de la BN. de Madrid. 
cripción realizada por su autor, Pedro de la Encina, no era tan perfecta como debiera porque contenía muchos errores; especialmente en aquello que se refería a los datos relacionados con la fecha de celebración de algunos capítulos generales así como en lo relativo al nombre de los maestres que los convocaron. Efectivamente, éste es el caso del documento que nos afecta, pero sólo en lo relativo a la fecha de celebración del Capítulo General puesto que en el mismo queda claro que se celebró en el maestrazgo de Pelay Pérez Correa ya que en los establecimientos correspondientes al mismo podemos leer que se celebró en la era de «mill dozientos e ochenta e siete annos", que como sabemos corresponde al año 1249 de la era cristiana.

El documento en cuestión ha llamado la atención de los tratadistas de la Orden de Santiago, no sorprenderá por tanto que algunos de ellos, guiados por los datos que tenían en sus manos, lo consideraran perteneciente al Capítulo General de 1249 mientras otros llegaron a encasillarlo dentro de un largo Capítulo General celebrado en Mérida entre los años 1271-1274. Sin embargo, ya hace unos años que resulta conocida la celebración en Mérida de dos capítulos generales dentro de la anterior horquilla cronológica y por ello no faltan estudiosos que consideran al documento del apéndice como emanado en el Capítulo General del año 1274, el último del maestre Pérez Correa, aunque tampoco faltan aquellos que lo consideran perteneciente al Capítulo General que los santiaguistas celebraron en Mérida en 1271.

Por lo que a nosotros se refiere, ya defendimos en su momento ${ }^{6}-\mathrm{y}$ seguimos haciéndolo a pesar de la insegura datación de este documento- que existen razones para creer que este establecimiento corresponde al Capítulo General del año 1271; pero como esas razones las veremos más adelante, habrá que descartar ahora por qué el establecimiento del apéndice no pertenece al capítulo de 1249. La primera razón que nos lleva a creerlo así es que en este último año la Orden se encontraba inmersa en una dinámica belicista muy intensa como para limitar la entrada de miembros en la misma de la manera tan brusca como se indica en dicho establecimiento. El segundo razonamiento en el que nos apoyamos es que, si nos centramos concretamente en los hombres que figuran mencionados en dicho establecimiento, como titulares de prioratos y encomiendas de la Orden, encontramos que ninguno de ellos las ocupaban en los años que rodean la mitad de aquella centuria y sí en los años setenta de la misma.

Pero antes de entrar en semejantes detalles habrá que indicar que los personajes mencionados en dicho establecimiento, aparte del maestre Pelay Pérez Correa, eran los priores y treces de la Orden en aquellos momentos. Siendo así, observaremos que nos faltan dos de aquellos comendadores ya que sólo se contabilizan 11 de ellos y no se mencionan los que podían faltar, ni los que «enme-

6 Nuestra tesis doctoral fue dirigida por el entonces catedrático de Historia Medieval de la UNED, José Luís Martín Rodríguez, y defendida en la Facultad de Geografía e Historia de esta universidad el día 19 de junio de 2002. 


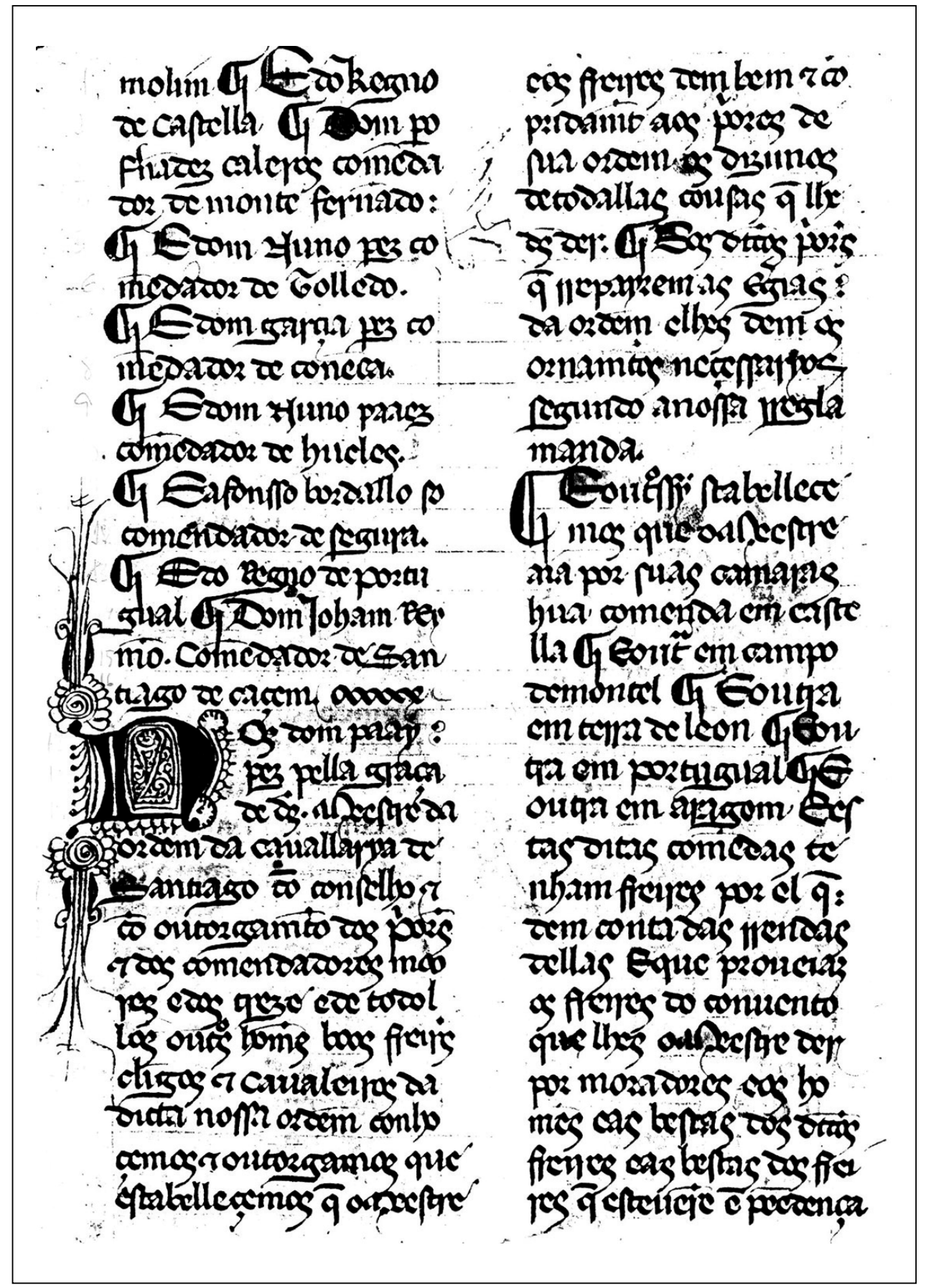

Figura 2. Fotocopia del folio 64r. del Livro de Santiago 140. Arquivo Nacional Torre do Tombo, Lisboa. 
daban» por los ausentes ${ }^{7}$. Ésta es otra de las omisiones del manuscrito en cuestión, pero se da la circunstancia que el documento que tratamos también podemos encontrarlo en lengua portuguesa ${ }^{8}$ y gracias al mismo podemos recomponer la totalidad de los treces santiaguistas; así sabemos que los que faltan en la relación castellana son el comendador de Cuenca, ínigo Pérez, y el de Santiago de Cacem, Juan Remondo. Eso sin mencionar que en la copia portuguesa figura Alfonso Bordallo como subcomendador de Segura de la Sierra y otras ligeras variaciones que afectan a nombres y apellidos de algunos de ellos.

Recomponiendo la relación a base de las copias castellana y portuguesa, tenemos que los priores de San Marcos y Uclés eran, respectivamente, Juan Martínez y fray Yague. Por otro lado, Gonzalo Ruiz Girón figura como comendador mayor de León y Pedro Núñez lo es del reino de Castilla; al frente de la encomienda mayor de Aragón encontramos a García Gómez y en la mayor de Portugal a Esteban Fernández; los treces correspondientes al reino de León son: Pay Núñez, comendador de Mérida, Fernán Pérez, comendador de Estepa y Aparicio Áriez, comendador de Montemolín. Los treces por parte de Castilla eran entonces: Pedro Fernández, comendador de Mohernando, Nuño Pérez, comendador del Hospital de Toledo, Iñigo Pérez, comendador de Cuenca, García Pérez, comendador de Uclés y Alfonso Bordallo, subcomendador de Segura. Nos falta otro hombre por mencionar y éste no era otro que el titular de la encomienda portuguesa de Santiago de Cacem, Juan Remondo, del que hemos de hablar más adelante por asuntos que vinculaban a la Orden y a la Corona de Portugal.

Sabiendo ya quiénes eran los hombres que figuraban al frente de prioratos y encomiendas, aportaremos algunas referencias documentales con relación a unos y otras para aclarar los motivos que nos llevan a fechar este documento en 1271. Por lo que se refiere a los priores, vemos que Juan Martínez aparece como titular del priorato de San Marcos ${ }^{9}$; pues bien, este prior ocupaba tal cargo en marzo de 1268 y lo seguirá ocupando en marzo de 1275. En torno a 1249 lo podía ocupar Pedro Estévanez ${ }^{10}$. Por lo que toca al priorato de Uclés, frey Yague lo era en aquellos momentos ${ }^{11}$; nos consta que lo fue desde 1266 y lo hizo de manera

7 Cuando al Capítulo General faltaba algún trece, era frecuente que su voto recayera en otro; entonces se hacía constar cuál de los presentes «enmendaba» la falta del ausente.

8 Arquivo Nacional Torre do Tombo; en adelante, (ANTT). Livro de Santiago 140. El establecimiento en cuestión comienza en el folio 63v. En este documento se data la reunión del Cabildo en la misma fecha y lugar que la copia castellana.

9 Este hombre era prior de San Marcos en el Capítulo General celebrado en Mérida en marzo de 1268 cuando se le conceden ciertas mejoras a Montiel. Véase así en CHAVES, Bernabé de: Apuntamiento legal sobre el dominio solar de la Orden de Santiago en todos sus pueblos. En adelante, (Apuntamiento legal). Madrid, 1740. Ediciones El Albir. Barcelona, 1975, folio 42v.

10 Pedro Estévanez era ya prior de San Marcos en enero de 1245. Véase en Archivo Histórico Nacional. Sellos, Carpeta 63, documento n. ${ }^{\circ}$ 2. En adelante, ( AHN. Sellos, 63/2). Con anterioridad había sido capellán del maestre Rodrigo Íñiguez.

11 El primer documento que hemos encontrado siendo este hombre prior de Uclés es: (AHN. Uclés, 262/3), fechado el 21 de octubre de 1263. No obstante, dejó el cargo durante algún tiempo en manos de Gonzalo Pérez -las razones las veremos más tarde-, para desempeñarlo luego durante muchos años. 
ininterrumpida hasta $1293^{12}$. En 1250 el cargo era desempañado por Pedro Fernánde $z^{13}$.

En lo referente a los comendadores mayores de los diferentes reinos vemos que la encomienda mayor de León viene ocupada por Gonzalo Ruiz Girón. Se da la circunstancia que este hombre figura al frente de dicha encomienda después de ocupar el mismo cargo en el reino de Aragón, a principio de los años setenta del siglo XIII; pues, como se puede ver en la documentación santiaguista, Gonzalo Ruiz Girón ya la ocupó con anterioridad a las de Cuenca, Estremera y Montalbán -ésta era la encomienda mayor del reino de Aragón-, encomiendas de las que también fue titular ${ }^{14}$. Pero en torno a 1249 la encomienda mayor de León la ocupaba Martín López y después le seguirían otros hasta 1261, cuando ya vemos de nuevo a Gonzalo Ruiz al frente de dicha encomienda. Por otro lado, el comendador mayor de Castilla lo es en el documento Pedro Núñez ${ }^{15}$; sabemos que este hombre ocupó tal cargo desde 1265 y siguió en el mismo hasta después de 1275. En el año 1249, el comendador mayor de Castilla lo era Pedro Pérez ${ }^{16}$, como comendador de Segura de la Sierra. En el documento que seguimos el comendador mayor de Aragón lo es don Garci Gómez ${ }^{17}$; este comendador figurará a partir de entonces, y hasta 1275, al frente de la encomienda mayor de Aragón. En 1249 era comendador mayor de Aragón, don Garci Garcés ${ }^{18}$. Finalmente, por lo que se refiere al comendador mayor del reino de Portugal, vemos que lo era Esteban Fernánde $z^{19} \mathrm{y}$ continuará en el cargo hasta marzo de 1275, por lo menos ${ }^{20}$. En 1249 era comendador mayor de Portugal, Gonzalo Pérez ${ }^{21}$.

12 Así en RIVERA GARRETAS, Milagros: La encomienda, el priorato y la villa de Uclés en la Edad Media (1174-1310). Consejo Superior de Investigaciones Científicas. Madrid-Barcelona, 1985, p. 527.

13 En 1250, 14 de agosto, encontramos a Pedro Fernández como «prior uclensis»; así en (AHN. Uclés, 339 /12).

${ }^{14}$ Gonzalo Ruiz Girón fue comendador de Montiel en 1243 (AHN. Uclés, 94/24) . En 1261 ya era comendador mayor del reino de León (AHN. Uclés, 339/13), pero las desavenencias con el maestre lo llevaron a la encomienda del Hospital de Cuenca (BN. Ms. 8.582, folio 66), Estremera (AHN. Uclés, 86/8) y Montalbán (Apuntamiento legal, folio 42). En el documento que seguimos aparece de nuevo como comendador mayor de León y lo será hasta la muerte de Pelay Pérez Correa, cuando fue elegido nuevo maestre de la Orden en marzo de 1275 (BN. Ms. 8.582, folio 67).

15 Pedro Núñez, al ser comendador de Segura de la Sierra, fue comendador mayor de Castilla desde 1265 (BN. Ms. 8.582, folio 66) y seguía siéndolo a finales de marzo de 1275 (BN. Ms. 8.582, folio 67 ).

16 Pedro Pérez murió en Tavira en 1249. Ya en 1253 encontramos al frente de la encomienda de Segura a Pedro Fernández Calleros.

17 Garci Gómez pasó a la encomienda de Montalbán procedente de la de Cuenca; aquí podemos situarlo en octubre de 1263 (AHN.Uclés, 262/3 ). Continuó al frente de la encomienda de Montalbán hasta ser sustituido en la misma por Alfonso Bordallo en octubre de 1275 (AHN. Uclés, 207/48).

18 A García Garcés lo encontramos al frente de la encomienda de Montalbán desde agosto de 1241 (AHN. Uclés, 221/2) hasta el año 1251 (BN. Ms. 8.582, folio. 61), año en que pasó a la encomienda del Hospital de Cuenca (AHN. Uclés, 243/15).

19 Es la primera vez que encontramos a este hombre al frente de la encomienda mayor de Portugal, pero sabemos que seguía siéndolo en marzo de 1275 (BN. Ms. 8.582, folio. 67 ).

20 Debemos indicar al respecto que nuestro estudio sobre comendadores y encomiendas termina con la fecha de la muerte del maestre Pelay Pérez Correa.

21 Gonzalo Pérez Magro fue comendador de Mértola, por tanto comendador mayor del reino Portugal hasta noviembre de 1257 (Livro . J. de Portel, documento XXXIX) y posiblemente hasta julio de 1258 (ANTT, Chancelaria de Afonso III, Livro I, folio XXVII). 
Por lo que a los treces del reino de León se refiere, dejaremos el caso de Estepa para el final; pero con respecto a la encomienda de Mérida vemos que el titular de la misma era Pay Núñez, del que no tenemos otra referencia anterior, aunque sí sabemos que figuraba al frente de la misma todavía en marzo de $1275^{22}$. En 1250 estaba al frente de la encomienda Guillermo Yáñez ${ }^{23}$. Por otro lado, el comendador Aparicio Áriez — que figura como titular de Montemolín—, también sigue al frente de esta encomienda en el establecimiento de marzo de $1275^{24}$. Sin embargo, en 1249 estaba al frente de la encomienda de Montemolín, Diego García ${ }^{25}$.

Con respecto a los treces del reino de Castilla, comenzaremos diciendo que Pedro Fernández Callero — hombre de amplia trayectoria en la Orden- se hizo cargo de la encomienda de Mohernando en 1265 y que todavía seguía al frente de ella el 31 de marzo de $1275^{26}$, pero debemos reconocer que no sabemos quién podía estar al frente de esta encomienda en 1249. Por otro lado, vemos como titular de la encomienda del Hospital de Toledo a Nuño Pérez; nos parece que llegó entonces a esta encomienda ${ }^{27}$, aunque no sabemos cuándo la dejó ya que falta en el establecimiento de marzo de 1275. Sin embargo, en los años centrales del siglo XIII parece que esta encomienda la ocupaba Martín López ${ }^{28}$. La figura de Íñigo Pérez al frente de la encomienda de Cuenca la tenemos documentada en el establecimiento que tratamos y también en el de marzo de 1275 . En 1246 estaba Rodrigo Bueso al frente de esta encomienda y en 1251 otro comendador llamado García García ${ }^{29}$. Por lo que al subcomendador de Segura se refiere, Alfonso Bordallo ${ }^{30}$, sabemos que ya ocupó este cargo en 1265; en 1270 estaba al frente de la encomienda de Cuenca y regresó a Segura como subcomendador en 1271, para pasar finalmente a ser comendador mayor de Montalbán en 1275. En lo relativo a la encomienda de Uclés, siguiendo a Rivera Garretas, podemos encontrar al comendador Garci Pérez entre $1271-74$ y 1276. En 1250, según esta autora ${ }^{31}$, ocupaba la titularidad de la encomienda Rodrigo Yáñez.

22 En esta encomienda podemos verlo en enero de 1275 ( AHN. Uclés, 198/15). El 31 de marzo seguía en el cargo (BN. Ms. 8.582, folio. 67 ).

23 Así en (AHN. Uclés, 211/13).

24 Es la primera referencia documental en la que encontramos a este hombre al frente de la encomienda de Montemolín; seguirá siéndolo hasta el 31 de marzo de 1275, al menos, (BN. Ms. 8.582, folio. $67)$.

25 Diego García era comendador de Montemolín en noviembre de 1249 (AHN. Uclés, 372/2) y lo seguía siendo en enero de 1254 (Crónica de la Orden de Alcántara. Tomo 1, p. 332).

26 Así en (B N. Ms. 8.582, folio 66), para 1265; (BN. Ms. 8.582, folio. 67), para 1275.

27 En el Capítulo General de 1269 encontramos a un comendador llamado Nuño Pérez al frente de la encomienda mayor del reino de León. Así en: «Colección de Pergaminos Medievales del Archivo de la Catedral de Badajoz", Carpeta n. ${ }^{1}$, documento 17. Publicado en Memorias de la Real Academia de Extremadura de las Letras y de las Artes. Volumen IV. Trujillo, 1998.

28 Así aparece en (AHN. Uclés, 243/15 ) fechado en diciembre de 1251.

29 Véase el documento de la nota precedente.

30 Los documentos relacionados con la trayectoria de este hombre son: para 1265 (BN. Ms. 8582, folio 66); para 1270 (AHN. Uclés, 99/29 bis); para su paso a Montalbán en 1275 véase (AHN. Uclés, 207/48).

31 RIVERA GARRETAS: La encomienda..., p. 539. En esta página aparecen los dos comendadores citados a modo de resumen de la documentación que maneja dicha autora. 
Nos faltan todavía las referencias a un comendador portugués y a otro del reino de León; con respecto al primero diremos que Juan Remondo debió hacerse cargo de la encomienda de Santiago de Cacem después de ser comendador mayor del reino de Portugal, cargo éste que detenta en un documento ${ }^{32}$ correspondiente al Capítulo General celebrado en Mérida en noviembre de 1269. Y el caso de la encomienda de Estepa nos resulta concluyente, pues este lugar no pasó al señorío de la Orden de Santiago hasta $1267^{33}$. Por tanto, resulta imposible que en un establecimiento de 1249 se mencionara a Fernando Pérez siendo comendador de Estepa ${ }^{34}$. No obstante, terminaremos diciendo que si contrastamos los nombres de los hombres que asistieron al Capítulo General reunido en Mérida el 31 de marzo de $1275^{35}$, veremos que la mayoría de estos hombres conservan las encomiendas que tenían en 1271; cosa muy difícil si el capítulo en cuestión se hubiera celebrado en 1249 dada la dinámica existente en la Orden en estos 26 años.

Con todos estos argumentos expuestos no tenemos más remedio que inclinarnos a datar el establecimiento que tratamos como correspondiente a la década de los años setenta del siglo XIII. Ahora bien, si nos hemos apoyado en los nombres de los personajes presentes en este capítulo para diferenciarlo de un posible cabildo celebrado en 1249, no podemos hacer lo mismo para determinar con mayor precisión que el texto en cuestión pertenece al Capítulo General de noviembre de 1271 y no al de marzo de 1274, que también se reunió en Mérida como hemos dicho. Para realizar esa diferenciación nos apoyamos en tres documentos santiaguistas, el primero fechado el 13 de noviembre de 1272, el segundo de ellos el día uno de agosto de 1273 y el tercero datado en marzo 1274, en el Capítulo General celebrado este año. En estos documentos se reflejan unas circunstancias concretas que nos llevaron en su momento ${ }^{36}$ a datar el texto del apéndice como perteneciente al año 1271.

La primera de ellas la encontramos en el documento ${ }^{37}$ de noviembre de 1272 cuando vemos al maestre Pelay Pérez Correa liquidando con sus almojarifes judíos una serie de gastos realizados por éstos en lugares pertenecientes al entonces reino de León, como son Montemayor (Cáceres) y Mérida (Badajoz), o al reino de Sevilla como es el caso de Cala (Huelva); Los lugares citados nada significarían si no se dijera luego en el documento que en aquellas cuentas quedaba por «... contar quanto vos tomo el comendador don Gonçalo Royz en Ribera e en Val de Meder».

32 Con este cargo podemos verlo en «Colección de Pergaminos Medievales del Archivo de la Catedral de Badajoz», Carpeta n. ${ }^{\circ}$ 1, documento 17; ya citado con antelación.

${ }^{33}$ GONZÁLEZ JIMÉNEZ, Manuel: Diplomatario andaluz de Alfonso X. Sevilla, 1991, documento n. ${ }^{\circ}$ 332.

${ }^{34}$ Fernán Pérez, al que algunos autores lo hacen hijo de Pedro Fernández de Albarracín, seguía siendo comendador de Estepa el 31 de marzo de 1275 (BN. Ms. 8.582, folio 67).

35 (BN. Ms. 8.582, folio 67v).

36 Cuando recopilábamos documentación santiaguista para escribir nuestra tesis; mantuvimos después esta postura porque no encontramos indicios en contrario.

37 (AHN. Uclés, 338/22). Lo podemos ver en RIVERA GARRETAS: La encomienda....; colección diplomática, documento n. ${ }^{\circ}$ 224.También en LÓPEZ AGURLETA, José: Bullarium Equestri Ordinis Sant lacobi de Sptha. En adelante (Bulario de Santiago). Madrid, 1719, p. 213. 
Como estos últimos lugares están dentro de la hoy provincia de Badajoz —Ribera es la actual Ribera del Fresno y Valdemeder es el afluente del río Matachel que pasa por Ribera-, nos parece a nosotros que el comendador don Gonçalo Royz del documento - que además tiene potestad para quedarse con dinero perteneciente a los judíos ${ }^{38}$ - debe ser Gonzalo Ruiz Girón cuando ya había vuelto al reino de León como comendador mayor del mismo. Ante esto último cabe preguntarse en qué se apoyaba el comendador Gonzalo Ruiz en noviembre de 1272 para apoderarse de ciertas cuantías que en el reino de León correspondía percibir a los judíos si, con anterioridad, no se hubiese dispuesto en Cabildo General que «ningund freyre ni pariente nin criado del maestre nin de comendador nin de freyres nin de iudio nin de moro, non coja nin recabe los derechos del maestre", aspecto que, efectivamente, queda reflejado en el establecimiento que tratamos.

Esta cita que acabamos de ver, y creemos que inducida por las mismas circunstancias, se repite en el documento fechado en Lorca en agosto de $1273^{39}$ cuando el maestre Pérez Correa hace una nueva liquidación con sus almojarifes judíos. Éstos debían sentir cierto temor a las consecuencias que podía acarrearles el arrendamiento de los derechos pertenecientes al maestre y puede, incluso, que hubiera sufrido en otras partes alguna situación parecida a la que los sometió el comendador Gonzalo Ruiz; los judíos debieron quejarse al maestre y éste, como era conocedor del peligro que corrían los judíos, dice en el documento que ahora comentamos: «Et se por ventura algun freyre o algun otro onne uos tomara o uos forçare alguna cosa destos lugares sobredichos [se refiere a los lugares arrendados a los judíos] nos somos tenudos de uollo fazer dar o de uollo recibir en nuestra cuenta».

Por otro lado, y esto resulta tan significativo como lo anterior, en el documento ${ }^{40}$ de marzo de 1274 vemos reflejadas unas circunstancias que sospechamos no se hubieran producido de no haberse decretado con antelación ciertos puntos relativos a la administración de las encomiendas de la Orden. Nos estamos refiriendo concretamente a la donación de sendas encomiendas que la Orden hizo a don Martín Anes do Vinhal y a lo que en ellas sucedió posteriormente; como ya dijimos en otras ocasiones ${ }^{41}$, estas encomiendas les fueron donadas al caballero portugués en el Capítulo General de 1269 y se vio obligado a presentar sus quejas ante el Capítulo General de 1274 porque los comendadores santiaguistas no respeta-

${ }^{38}$ La cita continúa diciendo: «...de todos vuestros derechos que vos y deviades aver, que sepamos cuanto es en cierto et nos que vollo recebiremos en conta».

${ }^{39}$ Nos estamos refiriendo a (AHN. Uclés, 219/4) y lo publica LOMAX: La Orden..., documento n. ${ }^{\circ} 33$. En el texto no se lee el mes, pero creemos que debió ser en agosto porque hay otro documento fechado también en Lorca el mismo día de ese mes y año. Véase (AHN. Uclés, 214/19).

40 (AHN. Uclés, 263/11.). Está publicado en nuestra tesis doctoral y en el trabajo indicado en la nota siguiente.

41 LÓPEZ FERNÁNDEZ, Manuel: «Medina de las Torres y Martín Anes do Vinhal. Un repoblador portugués en tierra de Extremadura». Revista de Estudios Extremeños, tomo LVIII, n. ${ }^{\circ}$ II. Badajoz, 2002. Las donaciones santiaguistas a Martín Anes, en compensación a las ayudas recibidas de éste, consistieron en la encomienda de Medina de las Torres, en el reino de León, y de Aguiar dos Padroes, en Portugal. 
ban ya la donación de posesiones a personas ajenas a la Orden. La presión era tal en 1274, que don Martín se personó en el Cabildo y no dudó en exigir la devolución del importe de todos los bienes que en tiempos anteriores había prestado a los santiaguistas, poniéndolos en un serio aprieto. Nosotros nos inclinamos a pensar que tales circunstancias no se hubieran dado si en un Capítulo anterior a 1274, fecha de la reclamación de Martín Anes do Vinhal, no se hubiera decretado o establecido que «todas las otras encomiendas - las que no pertenecían a la Mesa Maestral- con los derechos que le perteneçen sean dadas a los freyres de la dicha Orden e non a seglares, que le sean tomadas e dadas a los dichos freyles". Como esta cita literal corresponde al establecimiento que tratamos de datar con precisión, hemos de pensar que el mismo corresponde a lo decretado en el Capítulo de 1271 ya que los agravios a Martín Anes do Vinhal fueron anteriores al Cabildo de 1274, como ya hemos dicho.

A tenor de todo lo anterior, consideramos que la Mesa Maestral nació en el Capítulo General celebrado en Mérida en 1271 y, en este orden de cosas, nos interesa precisar en qué fecha se reunió este capítulo; dado que no contamos con ningún documento castellano donde se hable de este Cabildo, debemos apoyarnos en un documento portugués correspondiente a la Cancillería del rey Alfonso III de Portugal ${ }^{42}$, fechado en Mérida el 3 de noviembre. En dicho documento consta que el Capítulo General de la Orden y su maestre, Pelay Pérez Correa, nombraron entonces a Johanem Rymondi ...comendatorem Sancti lacobi de Caçem como procurador de la institución para intervenir en el litigio que los santiaguistas mantenían con la Corona de Portugal por la posesión de Tavira, Cacela y Castro Marín ${ }^{43}$.

Así que, una vez conocido todo lo anterior, creemos que no resulta disparatado datar el documento del apéndice como correspondiente al Capítulo General que se inició en Mérida ${ }^{44}$ el día primero de noviembre de 1271, pudiendo ser ésta la fecha de nacimiento de la Mesa Maestral en la Orden de Santiago.

\section{REFLEXIONES SOBRE ALGUNOS ASPECTOS DEL DOCUMENTO}

El establecimiento que seguimos resulta de interés para los historiadores de la Orden de Santiago porque la aplicación de su contenido debió suponer cambios acentuados en el funcionamiento interno de la misma. Quizá el más llamativo de esos cambios sea el de la creación de la más tarde llamada Mesa Maestral porque

42 ANTT. Chancelaria de Afonso III. Livro I folio CLIV.

43 El documento ha sido publicado por MARQUES, José: «Os castelos algarvios da ordem de Santiago no reinado de D. Afonso III». Actas das I Jornadas de Historia Medieval do Algarve e Andaluzia. Loulé, 1987, pp. 126-127.

44 En Mérida se celebraron Capítulos Generales en los años 1268, 1269, 1271, 1274 y 1275. Este último para elegir el sucesor del fallecido Pelay Pérez Correa. Nuestra opinión es que los mismos se celebraron en la iglesia de Santa Eulalia. Más detalles en nuestro trabajo: «Mérida y la Orden de Santiago en las décadas centrales del siglo XIII (1231-1274)». Revista de Estudios Extremeños, tomo LXV, n. ${ }^{\circ} 1$. Badajoz, 2009. 
ésta venía a romper el régimen económico de «mesa común», modalidad administrativa que había regido en la Orden desde su creación; por añadidura, existen en este establecimiento otros variados e interesantes aspectos que vistos en conjunto nos parece un "golpe de timón" al rumbo que hasta entonces había seguido la institución a lo largo de todo un siglo de existencia; tiempo en el que se había reafirmado, y de manera especial en los últimos años, la figura del maestre en detrimento de otro órgano de poder santiaguista como era el Consejo de los Trece.

Tratar este asunto en profundidad nos llevaría más espacio que el aquí asignado, así que sólo hablaremos de los aspectos económicos del documento. Estos asuntos son los primeros que nos encontramos en el documento cuando se habla de los diezmos y de las encomiendas; en lo relativo a los primeros, nada nuevo se dictamina porque seguirían siendo percibidos por los priores para atender los asuntos espirituales de la Orden; sin embargo, con respecto a las encomiendas ${ }^{45}$ - unidades económicas fundamentales dentro de la institución- nos encontramos con algo totalmente novedoso al disponerse, con respecto a ellas, que el maestre perciba las rentas que le proporcionen la administración directa de cinco encomiendas, situadas dos de ellas en el reino de Castilla y las otras en los reinos de León, Portugal y Aragón. De entrada, se podía pensar que los gastos generales de la Orden, afrontados por la Casa Maestral en primera instancia, se habían incrementado de manera notable y de este modo se resolvería la situación, pero realmente no era así; lo que se pretendía en la Orden era acometer una reforma económica de mayor calado y de la que saldrían beneficiados los comendadores de la Orden. Esto resulta palpable cuando se lee a continuación, «que todas las otras encomiendas [las que no fuesen asignadas al maestre] con los derechos que le pertenesçen sean dadas a los freyres de la dicha Orden e non a seglares, que les sean tomadas e dadas a los dichos freyles.

Ante esto último, resulta evidente que los freires santiaguistas no quieren que personas ajenas a la institución se beneficien de las propiedades de la misma, al tiempo que pretenden hacerse con los derechos señoriales de las encomiendas - hasta entonces en manos del maestre-y por ello piden que las no asignadas a éste le sean entregadas a los comendadores, pero no en las condiciones que hasta entonces las habían recibido, sino con todos sus derechos tal y como allí se explicita: "que las calonias, e el pie de altar, e los fornos, e las cuartas, e las fanegas, e los molinos, e las açennas sean de los comendadores". Y como aquello lo consideraban insuficiente, piden además ciertas garantías de estabilidad al frente de las encomiendas para sentirse motivados en la mejora de las mismas. No por otra cosa se establece: «porque los freires ayan mayor voluntad de reparar las cosas de la Orden que las encomiendas no le sean tomadas sino por sus meresçimientos». A tenor de lo que precede, todo apunta a que lo

45 En la documentación santiaguista se habla de dos tipos de encomienda: castillera y plana. Como podemos suponer, la tenencia de castillo supondrá una apreciable diferencia a favor de la primera, siempre más apetecida por su mayor rango. 
pretendido en el Capítulo General que nos incumbe era mejorar la situación personal de los comendadores a costa de coartar la potestad y derechos del maestre, al que económicamente se le asignan las rentas directas de cinco encomiendas repartidas por los diferentes reinos peninsulares.

Una vez conocido lo novedoso de la reforma, no podemos evitar preguntarnos qué estaba pasando entre los santiaguistas para romper súbitamente con el sistema económico por el que se habían regido a lo largo de un siglo. Para explicar esto último resulta necesario remontarnos a los orígenes de la Orden y saber que entre los santiaguistas la figura de los comendadores ya aparece en la bula confirmatoria de 1175 , e incluso con anterioridad se conoce el nombre de algunos de ellos ${ }^{46}$. Por tanto, las propiedades que recibían los santiaguistas de los monarcas de los diferentes reinos eran «encomendadas» a determinados freires que ejercían esa función de gobierno en las mismas como representantes de la institución, aunque dieran cuentas de su gestión al máximo representante de la Orden y al Capítulo General. En un principio puede que todos los comendadores fuesen freires santiaguistas, designados para esta función en los cabildos, pero antes del maestrazgo de Pelay Pérez Correa ya vemos que no todas las propiedades de la Orden estuvieron en manos de sus freires; no lo estaban porque la institución -siguiendo la dinámica de los diferentes monarcas y especialmente cuando escaseaba el numerario- compensaba con donaciones temporales a los seglares que habían prestado servicios a la misma, permutaba propiedades cuando alguien quería hacerse familiar santiaguista ${ }^{47}$, o bien entregaba alguna encomienda a determinados nobles para que éstos sacaran adelante su repoblación ${ }^{48}$; eso sin contar que también se hizo lo mismo cuando se quiso ganar voluntades políticas ${ }^{49}$. Aunque debe quedar claro que todas estas cesiones se hacían a título personal y finalizaban en el momento de la muerte del beneficiado.

Cuando Pelay Pérez Correa alcanzó el maestrazgo a finales de 1242, después de pasar por las encomiendas mayores de Portugal y Castilla, conocía bien estos mecanismos; sin embargo, no parece que los utilizara en demasía mientras duró la actividad reconquistadora hasta mediados del siglo XIII. En estos tiempos la Orden obtuvo muchas donaciones de las diferentes Coronas gracias a su esfuerzo militar

46 MARTÍN RODRÍGUEZ, José Luís: Orígenes de la Orden Militar de Santiago (1170-1195). Consejo Superior de Investigaciones Científicas. Barcelona, 1974.

47 Entre los documentos publicados, se puede observar estas circunstancias en el amplio apéndice documental que nos muestra la obra de RIVERA GARRETAS: La encomienda...; véanse al efecto los documentos $78,96,115,117,148,161,174$ y 186. Téngase en cuenta que los documentos corresponden solamente a tierras de la encomienda de Uclés.

48 Que sepamos, estos fueron los casos de las encomiendas de Alhambra y Villanueva de la Fuente; la primera fue entregada al conde don Álvaro de Lara en 1215 y la segunda a Ordoño Álvarez en 1232. Véase lo primero en Bulario de Santiago, pp. 61-63. Para el caso de Villanueva de la Fuente debemos ver AHN. Códice 1046-B. Libro III/1, pp. 273-274.

49 La entrega de Paracuellos de Jarama y Moratilla al conde don Álvaro de Lara en 1217 parece que tiene esta finalidad; también pudiera tratarse de un canje de propiedades porque el conde y su esposa quisieran hacerse familiares de la Orden, pero en el documento donde se realiza la permuta nada se dice sobre este vínculo. 
y en sus filas ingresaron miembros de destacadas familias hidalgas, pero también de otras menos pudientes porque la institución necesitaba efectivos para atender sus obligaciones militares. Fueron tiempos en los que se produjo la potenciación de la figura del maestre y también la centralización de la institución gracias a las donaciones recibidas de los monarcas, a la gestión de la casa maestral y, sobre todo, al respaldo personal del papa Inocencio IV a Pelay Pérez Correa en los primeros meses de 1246. Unos meses antes, el maestre había apelado al Papa porque el Consejo de los Trece había pedido su destitución por considerar que el cargo maestral no era vitalicio y que Pelay Pérez resultaba «pernicioso e inútil» para la institución ${ }^{50}$. No lo consideró así Inocencio IV y, como no podía ser de otra forma, después de recibir el apoyo del pontífice la figura del maestre se fue acrecentando y por ello en el establecimiento de 1251 se aprecia que destaca muy por encima de la del resto de los comendadores; también se aprecia en este último establecimiento que, por entonces, el conjunto de freires estaba bajo una rígida disciplina propia de la situación militar que se vivía. En aquellos momentos parece que el maestre tenía potestad para dar y quitar encomiendas planas mediante las cartas pertinentes, y nada podía objetar el comendador saliente al que, por otro lado, parece que no se le exige entrega de cuentas.

Pero todo esto cambió a principios de la segunda mitad del siglo XIII, al cesar la dinámica de la reconquista en Portugal y, especialmente, en Castilla poco después de la subida de Alfonso $X$ al trono castellano-leonés. Se produjo por entonces un cambio en la mentalidad de aquellos freires que eran caballeros, propiciada por la postura personal del monarca, abierto partidario de potenciar la dignidad de éstos $^{51}$; así que las cosas comenzaron a cambiar a la altura de 1259, fecha en la que el maestre fue obligado a reunir Capítulo General en Montánchez por disposición del Pontífice y del rey de Castilla, cuando sólo hacía unos meses que se había celebrado otro Capítulo General en Segovia. En el primer punto acordado en este Capítulo de Montánchez se señalaron una serie de preeminencias para los freiles caballeros que los diferenciaban de los que no lo eran; se determinó entonces, entre otras cosas, que los primeros llevaran una venera roja en el hábito como símbolo

50 El asunto lo tratamos con cierta amplitud en un capítulo de nuestra tesis; como resumen de la cuestión diremos que el maestre había procedido a nombrar algún miembro del Consejo de los Trece sin contar con la aprobación de la mayoría de sus miembros. Éstos decidieron entonces deponerlo por pernicioso e inútil; pero el maestre recurrió la decisión de los trece explicando la situación al Papa y pidiéndole que definiera los términos de «inútil y pernicioso». En su respuesta al contencioso, Inocencio IV, con anterioridad profesor de derecho canónico en Bolonia, mostraba que el maestre no era ninguna de las dos cosas y añadió que el cargo era vitalicio, como cualquier otro de carácter eclesiástico, si el nombramiento se hizo en su momento con la formalidad reglamentaria. Por lo que a las disensiones con los trece se refiere, vino a decir que el maestre no estaba obligado a nombrar a un miembro de los trece si a su juicio no lo veía conveniente para el cargo. Sin duda alguna, este respaldo del «apostólico» se hizo sentir en los años posteriores.

51 Una muestra de la misma podemos verla en la Ley XXIII, Título XII, de la Segunda Partida. Aquí, entre otras cosas que omitimos, se dice con respecto a los honores debidos a los caballeros: «....asi deven ser honrados de muchas maneras, de guisa que ninguno non debe estar en eglesia ante ellos, quando estuviesen a las oras, sino los perlados, o los otros clerigos que las dixesen, o los Reyes o los grandes señores, a que ellos oviesen de obedecer e servir.» 
distintivo, que se situaran en los lugares preferentes de las iglesias y, en caso de llegar a una encomienda cuyo titular no fuese caballero, se consideraría al freire caballero como comendador de la misma mientras estuviere allí. Y también se decretó por primera vez que un freire de la Orden no podía estar al frente de una encomienda castillera si no era hidalgo, además de reservarse la admisión de miembros en la Orden exclusivamente a los que fuesen caballeros.

A primera vista pudiera parecer que esta aristocratización santiaguista en el maestrazo de Pelay Pérez Correa fue propuesta por éste, sin embargo a nosotros nos parece que no fue así porque era romper con la trayectoria que había seguido la Orden y, sobre todo, porque estando de acuerdo el maestre con tal postura no hubiera sido necesaria la convocatoria de aquel Capítulo «por mandado del apostolico e del rey de Castilla e por ruego de los otros freyres» ${ }^{52}$. Lo más probable es que lo freires que «rogaron» aquella convocatoria debieron ser los que pudieran salir favorecidos de la medidas que allí se tomaran, y éstos no fueron otros que los caballeros hidalgos. De este modo el acceso a la cúspide de la Orden quedó reservado para los miembros de familias poderosas; éstos, conscientes de su clase social, no tardarían en crear problemas al maestre en un momento que la institución estaba paralizada en el plano militar, según hemos dicho. Detenida la reconquista muy pocas propiedades nuevas podían llegar a la Orden procedentes de los patronos reales, así que se procedió a captarlas por la vía de la familiaridad; o sea, apoyándose en el aspecto religioso de la institución. En este sentido se hicieron buenos y malos acuerdos ${ }^{53}$, acudiéndose también a la repoblación de los nuevos dominios santiaguistas; de todas formas la situación económica de la Orden no debía ser buena y el descontento campaba entre los más destacados miembros de la misma, razón por la que pedían reformas no aceptadas por el maestre y con el consiguiente malestar de aquellos. Así las cosas, surgió en 1263 un problema entre el maestre y el prior de Uclés, Fernando Pérez, que fue sustituido por fray Yague como resultas de aquellas discrepancias; entonces el sector reformista de los treces -entre lo que parece que destacaba Gonzalo Ruiz Girón, comendador mayor del reino de León- se opuso al maestre y éste procedió a la destitución de alguno de los treces rebeldes ${ }^{54}$.

El conflicto interno estaba servido; tan grave fue la situación que la Orden estuvo a punto de entrar en un cisma debiendo intervenir el papa Urbano IV y el mismo rey de Castilla para que no se llegara a tal estado. Debió ser entonces, al quedar destituidos, cuando el sector rebelde se negó a entregar al maestre las encomiendas castilleras que tenía a su cargo, hecho que debió impactar seriamente entre los miembros de la Orden y así queda reflejado en el Capítulo Gene64 r.)

52 Así podemos leerlo en el encabezamiento de dicho establecimiento. Véase (BN.Ms. 8.582, folio

53 «Pleytos» dice la documentación cuando se refiere a los acuerdos de familiaridad. Lo más negativos para la Orden se hicieron cuando se trató de captar a personajes que destacaban en la política de los distintos reinos con el fin de ganar voluntades, o potenciar la figura de la institución.

${ }^{54} \mathrm{La}$ bulas emitidas al efecto las publicamos en el apéndice documental de nuestra tesis. 
ral de 1440, cuando el Infante-Maestre don Enrique llega a decir ${ }^{55}$ que: «En tiempos del maestre don Pelayo Perez Correa, que Dios aya, nuestra Orden e religion padescio muchos dampnos e al dicho maestre vino grand detrimento por los cavalleros de nuestra Orden en aquella sazon que eran de gran linaje non les querer dar las fortalezas que tenian quando el maestre gelos demandava e aun al rey don Alfonso fijo del rey don Fernando, que entonces rregnava, gran deserviçio segund en la coronica del dicho maestre se cuenta».

Aquella crisis gestada en 1263 había finalizado en la primavera del año siguiente. Exceptuando el caso concreto de Gonzalo Ruiz Girón no conocemos a otros implicados, pero este hombre, de notable familia castellana ${ }^{56}$, lo estaba sin duda; de él nos dicen los comendadores Pedro de Orozco y Juan de la Parra, autores de la más antigua historia de la Orden de Santiago que hoy se conoce ${ }^{57}$, que: "deviera ser onbre bollicioso, i negociador, $i$ anbicioso de mas honrra i estado del que tenia en la orden. Dasele algun cargo por el levantamiento que fizo contra su maestre, deseando subçederle en la dignidat maestral, como claro paresçe, porque todavia la ovo de conseguir al fallesçimiento del dicho don Pelay Perez». Efectivamente, Gonzalo Ruiz Girón sucedió en el maestrazgo a Pelay Pérez Correa en 1275 , pero en 1264 , después de pedir el papa Urbano IV al maestre que no se tomaran medidas drásticas contra los rebeldes, debió ser trasladado de la encomienda mayor del reino de León a la del Hospital de Cuenca ${ }^{58}$, luego a la de Estremera ${ }^{59}$ y posteriormente a la de Montalbán ${ }^{60}$ que era la encomienda mayor del reino de Aragón. Ocupando este cargo intervino en la cruzada que organizó el rey Jaime I en Tierra Santa ${ }^{61}$ a la altura del año 1269 y esta acción, sin excluir su valía personal, debió rehabilitarle a los ojos del maestre que lo restituyó como comendador mayor del reino de León, tal vez en el momento de celebrase el Capítulo de 1271.

Por lo que estamos viendo, en la década de los años 60 del siglo XIII se estaba produciendo un cambio de mentalidad en buena parte de los miembros de la Orden; este cambio de mentalidad afectaba al concepto de la tenencia de «propio»

55 Citamos aquí parcialmente el capítulo XXV del Libro 1325-C, pero son varios los manuscritos que en el Archivo Histórico Nacional nos hablan del capítulo de 1440. También podemos verlo en el manuscrito tantas veces citado (BN. 8.582, folios 135-136).

56 Se lee en AHN. Códice 230-B, capítulo X, que «Gonzalo Ruiz Girón era hijo de Rodrigo Munioz Girón y sobrino de Juan Munioz, este último trece de la Orden. Siendo nieto, por tanto, de Munio Ruiz Girón y bisnieto de Rodrigo Gutiérrez Girón, mayordomo real hasta 1184. Éste, a su vez, era nieto del conde don Rodrigo González de Lara. Gonzalo Ruiz Girón, era familiar de los Cisneros y no hay indicios ni de bodas ni de hijos».

57 Según el marqués de Siete Iglesias fue escrita en 1488. Véase, Estoria de la Orden..., p. XIII.

58 Aquí estaba en marzo de 1265, según (BN. Ms. 8.582, folio 66).

59 En (AHN. Uclés, 86/85), aparece como comendador de Estremera en diciembre de 1267.

60 Ya era comendador aquí en marzo de 1268, según podemos ver en (Apuntamiento, folio 42. Podemos conocer algunos datos sobre su labor al frente de la encomienda en SÁINZ DE LA MAZA, Regina: La Orden de Santiago en la Corona de Aragón. La encomienda de Montalbán (1210-1327). Institución Fernando el Católico. Zaragoza, 1980.

61 Para más datos sobre este hecho véase CARRERAS CANDI, F: « La creuada a Tierra Santa (1269-1270)», en I Congreso de Historia de la Corona de Aragón, Barcelona, 1909, pp. 109-138. 
por parte de los freires, cada vez más decididos a marginar la propiedad comunal en beneficio de la propiedad privada; muestra de tal actitud es que andando el tiempo las encomiendas pasarán a ser consideradas como propiedades particulares de ciertas familias y pasarán, ya en el siglo XV, de padres a hijos sin traba alguna. Ese cambio - del que dice Lomax que pudo venir influenciado por el hecho de que muchos comendadores eran padres de familia ${ }^{62}$ - comenzó en el momento que los comendadores consiguieron en Capítulo General que se le concedieran los derechos señoriales de las encomiendas y ciertas garantías en las mismas para interesarse por ellas. Queda claro que el espíritu comunal de la Orden no daba los resultados económicos apetecidos porque, como es bien sabido, desde un punto de vista economicista, no merece la pena preocuparse por una empresa si no se tienen intereses personales en la misma. Esta falta de interés por la propiedad «encomendada» era negativa para todos y de aquí esa falta de liquidez del maestre y el bloqueo económico de la institución en los años 60 del siglo XIII, lo que sumado a las disputas internas de 1263 la llevó a una difícil situación cuando se declaró la rebelión mudéjar de $1264^{63}$. Terminada esta última la situación económica no mejoró, así que el maestre posiblemente comenzara entonces a aceptar ciertos cambios propuestos por el sector reformista ya que de otra manera no era posible que los comendadores, los únicos que podían y tenían medios para hacerlo, se interesaran por mejorar la productividad de sus encomiendas.

Así se llegó al reformista Capítulo de 1271 donde se determinó que la pérdida de derechos señoriales para el maestre, y por tanto de la administración central de la Orden, fuese compensada por las rentas de cinco encomiendas. Pero el cambio acordado no era fácil de ejecutar porque los primeros afectados por el mismo eran los propios treces ya que éstos - y en especial los comendadores mayores de los cuatro reinos- eran los titulares de las grandes encomiendas y no creemos que estuvieran dispuestos a prescindir de ellas. Por eso creemos que no se acordó entonces nada definitivo con respecto a qué encomiendas en concreto debían pasar bajo la administración directa del maestre. Mientras se llegaba a un acuerdo, la Casa Maestral debía seguir funcionando como lo había hecho hasta entonces; por tanto, el maestre debía seguir percibiendo los derechos que le correspondía a lo largo y ancho de las propiedades santiaguistas y afrontar los pagos de los asuntos generales que afectaban a la Orden. Pero como estas propiedades estaban muy dispersas y las rentas no eran de fácil recaudación, se conoce que Pelay Pérez Correa utilizaba un sistema basado en el arrendamiento de las mismas a terceros, entre los cuales había judíos.

Por lo que veremos a continuación, este sistema recaudatorio -o quizá las personas encargadas de ponerlos en práctica - no gozaban de las simpatías de los comendadores ya que en el Capítulo que nos incumbe también se dictaminó que: «ningund freyre ni pariente nin criado del maestre nin de comendador nin de freyres nin de iudio nin de moro, non coja nin recabe los derechos del maestre;

62 LOMAX: La Orden..., p. 212. 
mas por mandado del maestre, o de aquellos a quien el diere el poder, cojan dos onbres buenos e raigados que den buena cuenta e verdadera al maestre o a quellos que por el ovieren poder de poner estos cogedores segund dicho es. Se dictamina claramente en este Capítulo que los judíos no podían recabar los derechos del maestre y se da la circunstancia, según podemos leer en un documento ${ }^{64}$ de noviembre de 1272, que Pelay Pérez Correa ajusta cuentas con tres de ellos don Bueno, don Samuel y don Jacob- pudiendo enterarnos así que el comendador don Gonzalo Royz se había apoderado de ciertas cantidades que pertenecía cobrar a estos judíos en el reino de León. Este hecho concreto nos hace pensar, como ya dijimos, en la presencia de Gonzalo Ruiz al frente de la encomienda mayor del reino de León; al mismo tiempo, esa misma cita documental nos sirve para pensar que el comendador no hubiera procedido de igual forma de no contar con el respaldo legal de lo que se había establecido en un Cabildo anterior.

A tenor de lo expuesto hasta ahora, nos parece que lo establecido en el Capítulo General de 1271 supuso una ruptura total en el aspecto económico con la trayectoria anterior vivida en la Orden; ruptura que sin duda benefició a los comendadores y perjudicó al maestre. Abundando en tal sentido diremos que, hasta en lo referente al yantar, tuvo repercusiones puesto que dicho servicio se llegó a limitar para el maestre y los comendadores mayores, estableciéndose al respecto: «que el maestre nin los comendadores mayores non coman en las encomiendas si non una vez en el anno, e no mas; nin con mas gentes que las que deue de traer segund el nuestro ordenamiento ${ }^{65}$. Para añadir luego que «sy vianda o presentes sobraren, finquen al comendador de la casa. En este orden de cosas también se decretó que ni el maestre ni los comendadores mayores quitaran "a los otros comendadores las caualgadas ni las aventuras que les acaesçieren en las sus encomiendas". Entendemos que se están refiriendo a la quinta parte del botín proveniente de tales cabalgadas y que antes debían percibir los maestres como titulares del señorío de la Orden ${ }^{66}$.

Sin muchas dudas por nuestra parte, diremos que en el Capítulo General de 1271 se trató de corregir aspectos poco favorables para los comendadores en la etapa inmediata anterior, al limitar potestades que se había arrogado el maestre. Ese autoritarismo precedente de Pelay Pérez Correa pudo ser el motivo para que

63 Lomax observa que a la Orden esta rebelión le cogió «descuidada y le costó trabajo reaccionar». Así en: La Orden..., p. 210. En estas circunstancias económicas fue cuando recibieron los santiaguistas una importante ayuda por parte de Martín Anes do Vinhal.

64 Véase (AHN. Uclés, 338/22). Lo publica RIVERA GARRETAS: La encomienda..., documento n. ${ }^{\circ}$ 223.

65 En el capítulo de 1251 trata de fijar los séquitos que debían acompañar a priores y comendadores; al maestre no se le ponen limitaciones, pero en 1271 se decretó en con respecto al séquito del maestre «que en tiempo que la Orden non oviere guerra con los moros nin el rey llamare a su seruiçio, el maestre traiga consigo diez freyres escuderos de cauallo e treynta onbres de pie e los ofiçiales que menester ovieren de poner de pie e de caballo».

$66 \mathrm{El}$ «quinto del botín» era un derecho que correspondía percibir al rey, pero en aquellas encomiendas en las que el monarca lo había cedido a la Orden debió de percibirlos el maestre o los comendadores mayores de los distintos reinos. 
se estableciera entonces que, en lo sucesivo, el maestre no pueda quitar caballos, armas y otras propiedades a los freires con la excepción de que fuese en caso de guerra, o en extrema necesidad; de todas formas quedaba el maestre obligado a restituir tales cosas cuando terminara la campaña y a proporcionar caballos de las yeguas de la Orden ${ }^{67}$. Los freires en general ganan competencias frente al maestre, pero no cabe duda de que los más mas beneficiados serán aquellos que procedan de familias hidalgas porque también se dictamina que «...ningun freyre de la nuestra Orden si non fuere fidalgo legitimo non pueda aver estado de los trece nin pueda tener castillo...». Resulta ésta una señal inequívoca del claro predominio de la clase nobiliaria en el seno de los santiaguistas; situación que queda ampliamente demostrada cuando se ratifica que en la institución sólo se admitirán hidalgos caballeros en calidad de freires, llegando a expulsar de la Orden al que no cumpliera estos requisitos ${ }^{68}$.

Sin querer extendernos más en estos asuntos y por si quedara alguna duda de que la clase nobiliaria dominaba ya el Consejo de los Trece y que éstos, además, no estaban dispuestos a permitir las veleidades del máximo dignatario de la Orden, se determina entonces "que el sello del cabildo lo tenga uno de los treze que ellos touieren por bien e non el maestre».

\section{LAS CONSECUENCIAS DEL NACIMIENTO DE LA MESA MAESTRAL}

En el contexto ideológico que acabamos de ver resulta difícil admitir que la ruptura de la «mesa común» y la aparición de la Mesa Maestral surja en la Orden de Santiago como una imposición de Pelay Pérez Correa. A pesar de la autorizada opinión del profesor Carlos de Ayala Martínez ${ }^{69}$, nosotros pensamos que más bien fue al contrario; nos lo parece así porque los comendadores ganan terreno frente al maestre en todas las disposiciones de tipo económico establecidas en el Capítulo que nos incumbe. Por tanto, nos vemos obligados a pensar que el ma-

67 Estas disposiciones en concreto dicen: Otrosi, stablesçemos que el maestre non sea poderoso al freyle cauallo nin mula ni armas de ge lo quitar, syno para el rey e para su cuerpo quando fuere en guerra; e despues que sallere de la guerra que las dichas cosas que las den al freyle que fueron tomadas. Otrosi, las dichas cosas e otras semejantes puedan tomar al freyle para conprar pan si la casa de la Orden fallesçiere; en las yeguas de la Orden todavia dando cauallo al dicho freyre conque sirva a Dios e a su Orden.

68 Lo puntos establecidos al respecto señalan: Otrosy, establesçemos que el maestre ni los comendadores non den el el (sic) abito de nuestra Orden sinon a onme fidalgo e que sea primeramente cauaIlero asi conmo de suso avemos stablesçido; e si lo dieren a otro, denlo conmo a siruiente dando de sus heredades a la Orden de que la Orden se aproueche; e otra miente mandamos en virtud de santa obediençia que tal onme non sea acogido, e si fuere acogido si non conmo dicho avemos, seale tirado el abito e sea echado de nuestra Orden.

69 Véanse su trabajos al respecto entre los que podemos citar: «Las órdenes militares en el siglo XIII castellano. La consolidación de los maestrazgos". Anuario de Estudios Medievales, n. ${ }^{\circ}$ 71/1, Barcelona 1997, pp.239-279. «Maestres y maestrazgos en la Corona de Castilla (siglos XII-XV)». En Las órdenes militares en la Península Ibérica. Volumen I. Edad Media. Ediciones de la Universidad de Castilla-La Mancha. Cuenca, 2000, pp.325-378. Las órdenes militares hispánicas en la Edad Media (siglos XII-XV). Editan, Marcial Pons y Latorre Literaria. Madrid, 2003, pp.205-208. 
estre Pérez Correa hubo de aceptar la postura señalada por los comendadores reformistas en lo referente al reparto de encomiendas y a la pérdida de atribuciones del maestre. Ahora bien, admitida tal situación cabe preguntarse cómo es posible este cambio tan acentuado en la Orden durante el maestrazgo de un hombre que pasa por ser uno de los maestres más centralizadores de la misma, apoyándose para dicha labor en la llamada Casa Maestral ${ }^{70}$, organismo compuesto por oficiales expertos en los distintos y variados asuntos que podían afectar a la Orden $^{71}$.

Si tenemos en cuenta el recorte de prerrogativas que sufre el maestre en los establecimientos que seguimos, nos inclinamos a creer que Pelay Pérez aceptó el cambio sin ser un abierto partidario del mismo y que se debió sentir forzado a llegar a un acuerdo con los reformistas por la falta de liquidez y el bloqueo económico que atravesaba la Orden; ya hemos dicho al respecto que los comendadores no estaban dispuestos a sacrificarse en lo económico para potenciar la repoblación de sus encomiendas si no recibían los derechos pertenecientes a las mismas y, de alguna manera, se le garantizaba su titularidad sin quedar expuestos a la voluntad del maestre. El sistema económico seguido hasta entonces en la Orden consistente en la propiedad de tipo comunal, la entrega de algunas encomiendas a seglares para que las potenciaran, los cambios de encomiendas para atraer familiares, así como la sustitución de los comendadores menos competentes, no había alcanzado las expectativas deseadas en la última etapa del maestre Pérez Correa, a pesar de las extensas propiedades de los santiaguistas.

Ante semejante fracaso, es probable que el maestre acabara por ceder ante las pretensiones de los reformistas en los años finales de su vida; creemos que inicialmente pudo resistirse a las reformas propuestas —aparte de que podía salir perjudicado- porque suponían romper con un siglo de tradición administrativa, eso sin descartar que intuyera por entonces que aquel era uno de los caminos que podía apartar a los miembros de la Orden de la propiedad comunal y del seguimiento del voto de pobreza ${ }^{72}$, conceptos éstos que ya se reflejaban en la bula con-

70 La casa maestral debió aparecer muy temprano en la Orden a pesar de que nada se diga de ella en la bula confirmatoria de 1171. Era como una prolongación del maestre en los diferentes campos de su gestión y estaba encabezada por un mayordomo. Parece ser que uno de los maestres que más la potenció fue Pedro González, a partir precisamente de la fusión de los reinos de Castilla y León. De hecho, en abril de 1231 (Bulario de Santiago, p. 142 ) tenemos noticia de un mayordomo de este maestre llamado Jimeno Pérez que sigue ocupando el mismo cargo en marzo de 1236 (AHN. Uclés, 94/21. En tiempos del maestre Pelay Pérez Correa conocemos a dos mayordomos distintos: Blasco Pérez (AHN. Uclés, 214/12) y Lorent Armíllez (AHN. Uclés, 94/28).

71 Estos oficiales son a los que se refieren los establecimientos de 1271 cuando dicen que al maestre podían acompañarle todos los "ofiçiales que menester oviere de poner, de pie e de cavallo».

72 El concepto de pobreza fue variando en la Orden a lo largo del tiempo. En la bula confirmatoria se viene a decir: «debéis vivir con toda humildad y concordia, sin bienes propios». En el Capítulo de 1251 se establece todavía: «quien touiere propio sea descomulgado e anatematizado en la iglesia en dia de Navidad o en dia de Pascua de Resurreçion o en la fiesta de Pentecostes ante que comulgue, e maldiganlo con candelas ençendidas e despues amatenlas con agua». Sin embargo, a partir de los tiempos que aquí tratamos este criterio se fue relajando de manera acentuada y en el siglo XV se reconocerá abiertamente la propiedad privada. 
firmatoria del papa Alejandro III en 1175. La muestra de que podía ser así, y a la larga se manifestó abiertamente, la tenemos en que no se tardó mucho en dar el paso siguiente en tal dirección cuando en el primer Capítulo General que convocó el maestre Gonzalo Ruiz Girón —en León, abril de 1275-, se autorizó más prerrogativas a los comendadores en el sentido de concederles, «por todos los días de sus vidas", las nuevas pueblas que habían hecho o hicieran en un futuro ${ }^{73}$. Dadas las circunstancias antes señaladas, parecía ésta la mejor manera de que los freires con cierto poder económico - no podían ser otros que los provenientes de familias hidalgas - acometieran la repoblación de las numerosas propiedades de la Orden y dinamizaran la actividad económica de la misma; pero el proceso de adquirir derechos con respecto a las encomiendas por parte de los comendadores no se detuvo aquí, porque, como bien señala el profesor Carlos de Ayala, en 1299 algunos comendadores fronterizos ya amenazaron con «entregar sus fortalezas a los musulmanes si no les era reconocida esa tenencia vitalicia» ${ }^{74}$.

Como bien se sabe, dicho proceso fue más allá, pero no es nuestra intención detenernos en los detalles de cómo se pasó de la propiedad comunal a la privada en el seno de la institución santiaguista; lo que aquí seguimos es el origen y evolución de la Mesa Maestral, así que ahora hemos de reiterar que lo acordado en el Capítulo General de 1271 con respecto al reparto de encomiendas en el seno de la Orden no se llevó a efecto inmediatamente. El cambio hubo de ser progresivo y paulatino para que nadie saliera perjudicado; y si a la larga se produjo en toda su extensión, el maestre debió salir perjudicado en el momento que hubo de atender a los gastos generales de la Orden durante las invasiones benimerines, o en las dificultades sufridas en los tiempos correspondientes a la minoría de edad de Fernando IV de Castilla. En este tiempo parece que el maestre Juan Osórez (12921310) se vio avocado a tomar otras encomiendas para su cámara si tenemos en cuenta lo que se determina en el Capítulo General de $1310^{75}$. En muchos aspectos parece que con anterioridad a esta fecha se había vuelto a los tiempos del maestre Pelay Pérez Correa y por ello el maestre Juan Osórez se compromete a devolver las encomiendas tomadas a los comendadores y quedarse con cuatro encomiendas para su cámara, no cinco, porque no podía hacerlo así en el reino de Aragón. Como se sabe, el maestre Juan Osórez no llevó a cabo esta reforma porque dimitió en ese mismo Capítulo y en los años posteriores la Orden vivió una etapa difícil hasta el punto que los comendadores mayores conspiraron contra el maestre Diego Muñiz ${ }^{76}$. En resumen, hacer efectiva aquella secesión planeada en 1271 no fue fácil y en realidad no sabemos cuándo ni cómo se fue perfilando para que a fines de la Edad Media los bienes de la mesa maestral santiaguista alcanzaran aproximadamente el 50 por ciento de la base rentista de la Orden ${ }^{77}$.

73 (Bulario de Santiago.., p.221).

74 AYALA MARTÍNEZ: «Las órdenes militares hispánicas...», p. 349. También en : «Las órdenes militares en el siglo XIII...,» p. 278.

75 Véanse los detalles en (Bulario de Santiago, p. 261).

76 AYALA MARTÍNEZ: «Las órdenes militares en la Península Ibérica...», p. 214.

77 Ibidem, pp. 355-356. 
Semejante porcentaje, suponemos nosotros, no se hubiera alcanzado de recibir el maestre una sola encomienda en cada reino, al menos que las encomiendas asignadas a la Mesa Maestral hubieran sido muy grandes, o muy rentables. Desde luego, el paso de grandes encomiendas bajo la administración directa del maestre no se dio hasta finales del siglo XIV — caso de Jerez de los Caballeroso ya en el siglo XV — caso de Montánchez, Uclés ${ }^{78}$ y tal vez Ocaña-. En tiempos anteriores resulta mucho más conocida la pertenencia a la Mesa Maestral de numerosas dehesas y el ingreso en la misma de pequeñas encomiendas surgidas en el seno de otras mayores, como fueron los casos de Llerena, Villanueva de Alcardete, Puebla de don Fadrique, Villanueva de los Infantes, y posiblemente otras que ahora se nos escapan. En general - según se aprecia en la documentación y en estudios santiaguistas ${ }^{79}$-, se podía decir que a partir de 1271 los maestres santiaguistas tuvieron repartidas sus fuentes de rentas a lo largo y ancho de las propiedades de la Orden, tal y como las habían tenido desde su fundación. En resumen, que la traumática escisión propuesta en los establecimientos que seguimos no se llevó a cabo tal y como se pensó en un primer momento, aunque los comendadores sí pudieron apropiarse de los derechos que reclamaban en las encomiendas por ellos gobernadas. Creemos que fue así porque tal punto se vuelve a ratificar en el Capítulo donde se eligió maestre a Gonzalo Ruiz Girón, en marzo de 1275 , donde además se determina y precisa que «los bastimentos sean comendados", como si se tratara de un punto que había quedado sin definir en los establecimientos que tratamos y que por esa razón siguió administrando el maestre.

Así las cosas -el maestre sin administrar encomiendas concretas y los comendadores disfrutando de los derechos de sus encomiendas- habrá que preguntarse cuáles fueron las rentas que siguió percibiendo el maestre Pelay Pérez Correa para afrontar los gastos derivados de la administración centralizada de la Orden. La verdad es que el asunto no está lo suficientemente claro, pero puede que esos ingresos provinieran de los mismos derechos que ya tenía adquirido de tiempos anteriores y de los cuales tenemos una muestra en los documentos donde el maestre y sus almojarifes judíos ajustan las cuentas de las rentas que correspondían al primero, aunque sólo podamos verlo en una parte de las propiedades de la Orden: las que se extendían entre la Sierra de Guadarrama y Murcia incluyendo toda la Sierra de Segura.

Los documentos a utilizar en esta ocasión los publica Lomax en su tesis doctoral ${ }^{80}$ y corresponden a los años 1273 y 1274 . Los dos correspondientes al año

78 Para las encomiendas situadas hoy en tierras extremeñas podemos consultar RODRÍGUEZ BLANCO, Daniel: La Orden de Santiago en Extremadura en la Baja Edad Media (siglos XIV-XV). Excma. Diputación de Badajoz. Badajoz, 1985. Para las encomiendas santiaguistas en Castilla-La Mancha véase PORRAS ARBOLEDA, Pedro Andrés: La Orden de Santiago en el siglo XV. La provincia de Castilla. Dykinson-Caja Provincial de Ahorros de Jaén. Madrid, 1993.

79 Consúltese (Apuntamiento legal) de Bernabé de Chaves o cualquiera de las tesis doctorales citadas en la nota anterior.

80 Nos referimos a los documentos 31, 32 y 33 del apéndice documental de la obra tantas veces citada: La Orden de Santiago..., 
1273 están fechados en Lorca el día primero de agosto; el primero de estos documentos (AHN. Uclés 214/19) corresponde a la liquidación de la cuentas anteriores a la fecha de la data, mientras que en el segundo de ellos (AHN. Uclés, 219/13) se fijan las condiciones económicas para arrendar a los judíos las mismas rentas que ya habían tenido el año anterior. No vamos a entrar en detalles sobre los lugares que se citan, pero sí hablaremos de los derechos a percibir por el maestre; en tal sentido vemos que casi todos los derechos del maestre corresponden a diezmos, pechos de sus vasallos musulmanes, montazgos y portazgos, además de «los nuestros dos bastimentos ${ }^{81}$ que nos avemos desde Boytrago fasta Guadarmena", pero no se citan los derechos señoriales correspondientes a monopolios pertenecientes a molinos y hornos que antes debía percibir el maestre - según deducimos de la lectura del establecimiento de 1271-, pero que a partir de esta fecha debieron pasar a los comendadores.

El alquiler de estas rentas le había costado a los judíos 32.000 maravedíes entre junio de 1272 y junio de 1273; pero en esta última fecha la cantidad que están dispuestos a pagar los arrendatarios sufre una bajada ostensible ya que se queda en 13.000 maravedíes en moneda y 2.400 cahices de cereales. Como la cantidad total del arriendo entre junio de 1273 y 1274 no superaría los 17.800 maravedíes, incluyendo el precio del cereal ${ }^{82}$, vemos que la diferencia de un año a otro desciende en unos 14.200 maravedíes $^{83}$. Pues bien, si ya la diferencia del arriendo de las rentas del maestre desciende entre 1273 y 1274 , otro tanto ocurrirá entre este último año y 1275 porque el importe de lo arrendado a los judíos en mayo de 1274 (AHN. Uclés, 219/4) se queda sólo en 9.500 maravedíes. Se podían decir muchas cosas al respecto, pero cuando vemos que entre los lugares arrendados a los judíos en mayo de 1274 ya no entra la encomienda de Aledo y Totana, ni tampoco los dos bastimentos de la Orden en las zonas de la Ribera del Tajo y Campo de Montiel, no podemos dejar de pensar que la acción de los comendadores se estaba dejando notar en detrimento de los derechos maestrales.

\section{CONCLUSIÓN}

Después de cuanto precede, quizá no sea necesario insistir en que la Mesa Maestral nació en el seno de la Orden de Santiago como consecuencia de las aspiraciones de los comendadores, más que por las pretensiones del maestre encaminadas a crearse una plataforma económica bajo su directa administración.

81 MATELLANES MARCHAN, Vicente: «La estructura de poder en la Orden de Santiago, siglos XIIXV». En la España Medieval, n. ${ }^{\circ} 23$. Madrid, 2000, p. 309.

${ }^{82}$ El precio de este cereal podía ascender a unos 4.800 maravedíes promediando el valor del cahiz a 2 maravedíes. Para esto hemos tenido en cuenta que el cahiz tiene 12 fanegas y que 5 fanegas valían un maravedí en 1265, cuando el trigo estaba caro. Así en (BN. 8.582, folio 65v).

${ }^{83}$ Esta reducción no se puede confundir, a pesar de ser muy próxima, con los 14.113 que, por diferentes conceptos, habían cobrado los judíos en nombre del maestre. 
Sinceramente creemos que los maestres habían conformado esa plataforma a lo largo de los años mediante la reserva de ciertas posesiones y determinados derechos, entre los que se encontraban los que luego reclamaron los comendadores, en las múltiples y variadas posesiones santiaguistas. Las rentas proporcionadas por esas propiedades y derechos fueron administradas por la Casa Maestral hasta que el sector reformista de la Orden impuso su propuesta de entregar determinadas encomiendas al maestre y quedarse ellos con parte de los derechos que correspondían al máximo mandatario de la Orden. Pero la reforma no se llevó a efecto tal y como estaba proyectada inicialmente; los comendadores sí se quedaron con los derechos solicitados por ellos en sus encomiendas, pero el maestre Pelay Pérez Correa sólo percibió las rentas del resto de derechos y bienes que ya tenía.

Por ello consideramos - ayudado también por lo ocurrido en tiempos del maestre Juan Osórez- que lo establecido en el Capítulo General de 1271 perjudicó al maestre y benefició a los comendadores, siendo éste el primer paso de los freires santiaguistas hacia la tenencia de propio dentro de la Orden de Santiago, circunstancia que rompía con el voto de pobreza observado hasta entonces en la misma. Este objetivo -el de la tenencia de propio en el seno de la institución santiaguista - no tardaría en alcanzarse e incluso acentuarse y reconocerse por el Papa ya a finales del siglo XIV; así las cosas, no puede sorprendernos que a finales del siglo XV determinadas encomiendas se presenten como «el dominio de ciertas familias que se transmiten cargo y heredad dentro de su círculo" ${ }^{84}$. A pocos historiadores se les escapa este proceso interno dentro de la Orden y al respecto dice Lomax que «el ideal religioso-guerrero que había inspirado a los freires, [a los santiaguistas] cambió lentamente hacia el de caballero cortés de los romances en quien honra y riqueza se anteponen al favor de Dios» 85 . En el mismo sentido, hablando de la evolución mental vivida en el seno de la Orden desde su fundación, viene a decir el profesor José Luís Martín que los caballeros santiaguistas del siglo $\mathrm{XV}$ se encuadran en el retrato de la nobleza mundana a la que pertenecen, mejor que en el espejo de virtudes que San Bernardo ofreció a los caballeros templarios en el siglo XIII86.

${ }^{84}$ RODRÍGUEZ BLANCO: La Orden..., p. 130.

85 LOMAX: La Orden..., p. 100.

${ }^{86}$ MARTÍN RODRÍGUEZ: "Los fueros de la Orden de Santiago en Castilla-La Mancha». En Espacio y fueros en Castilla-La Mancha. Editorial Polifemo. Madrid, 1995, p. 184. El autor nos ilustra con una cita de Bernardo de Claraval al contrastar la diferencia que éste apreciaba entre la «milicia de Cristo» y la caballería seglar. 


\section{APÉNDICE DOCUMENTAL}

Establecimiento de la Orden de Santiago en el que se instituye la Mesa maestral en dicha institución.

BN. Manuscrito 8582.

[folio 44v]

Stablesçimientos fechos en el Cabildo General fecho en Merida seyendo maestre don Pelay Perez Correa en la era de mill e dozientos e ochenta e siete annos: Estos son los stablesçimientos que fueron fechos e otorgados en el Cabildo General que fue fecho e çelebrado en Merida en la era de mill e dozientos e ochenta e siete annos seyendo maestre don Pelay Perez Correa, e el prior de Sant Marcos don Juan Martinez, e el prior de Ucles don Frey Yague, e comendador mayor de Leon don Gonçalo Ruys Giron, e comendador mayor de Castilla don Pero Nunnez,

\section{[folio 45r]}

comendador mayor de Aragon don Garçi Gomez, e el comendador mayor de Portugal don Esteuan Fernandez; e los treze del reyno de Leon, Pero Nunnez comendador de Merida, e Fernando Perez comendador de Stepa, e Apariçio Annayz comendador de Montemolin; e del reyno de Castilla Pero Fernandez Callero comendador de Monte Fernando, e don Nunno Perez comendador de Toledo, e don Garçi Perez comendador de Ucles, e Alfonso Bordallo comendador de Santiago de (borrado). Nos, don Pelay Perez por la gracia de Dios maestre de la Caualleria de Santiago con conseio e otorgamiento de los priores e comendadores mayores e de los trece e de los otros onmes buenos freyres caualleros de la dicha Orden conosçemos e otorgamos e stablesçemos que el maestre e los freyles den bien e conplidamente a los priores de su Orden los diezmos de todas las cosas que les Dios diere; e los dichos priores que repartan las iglesias de la Orden e les den los ornamentos nesçesarios segund la nuestra Orden manda. Otrosy, stablesçemos que el maestre aya por sus camaras un encomienda en Castilla, e otra en el Canpo de Montiel, e otra en tierra de Leon, e otra en Portogal, e otra en Aragon e estas dichas encomiendas tengan freyres por el que le den cuenta de las rentas de ellas, e que prouean a los freyres de los conventos que les el maestre diere por moradores; e los onmes de los dichos

[folio 45v]

freyres que estouieren en penitençia, que aprendan la Regla e que todas las otras encomiendas con los derechos que le pertenesçen sean dadas a los freyres de la dicha Orden e non a seglares, que les sean tomadas e dadas a los dichos freyles. Otrosy, establesçemos que si algund onme fidalgo viniere pedir el abito de la nuestra Orden e quisiere ser nuestro freyre no sea asi resçibido nin le sea 
dado el dicho abito de ser primeramente cauallerero. Otrosy, establesçemos e defendemos que ningund freyre de la dicha nuestra Orden si non fuere fidalgo legitimo non pueda aver estado de los trece nin pueda tener castillo; e el que lo oviere tomare (sic) sabiendo que non es tal conmo dicho es, pierda la encomienda e el cauallo e las armas e cosa que el en la dicha Orden dixere o fisiere non vala e rrepientase por penitençia de un anno. Otrosy, establesçemos que el sello del cabildo lo tenga uno de los treze que ellos touieren por bien e non el maestre. Otrosy, establesçemos que el maestre non pueda acusar nin prender freyre sinno conmo manda la Regla. Otrosy, establesçemos que el maestre ni los comendadores non den el el (sic) abito de nuestra Orden sinon a onme fidalgo e que sea primeramente cauallero asi conmo de suso avemos stablesçido; e si lo dieren a otro, denlo conmo a siruiente dando de sus heredades a la Orden de que la Orden se aproueche; e otra miente

\section{[folio 46r]}

mandamos en virtud de santa obediençia que tal onme non sea acogido, e si fuere acogido si non conmo dicho avemos, seale tirado el abito e sea echado de nuestra Orden. Otrosi, stablesçemos que el maestre non sea poderoso al freyle cauallo nin mula ni armas de ge lo quitar, syno para el rey e para su cuerpo quando fuere en guerra; e despues que sallere de la guerra que las dichas cosas que las den al freyle que fueron tomadas. Otrosi, las dichas cosas e otras semejantes puedan tomar al freyle para conprar pan si la casa de la Orden fallesçiere; en las yeguas de la Orden todavia dando cauallo al dicho freyre conque sirva a Dios e a su Orden. Otrosi, stablesçemos que ningund castillo de la orden nin maestre nin comendador mayor ni otro freyre ninguno non aya poder de lo dar en ninguna guisa e a ningund onme seglar. Otrosi, stablesçemos que todo freyre sea tennido de fazer su menester, el por que antes solia benir en el siglo, e sy por esto se ensannare e saliere de la Orden sea preso e metido en fierros e todavia faga su menester. Otrosi, stablesçemos que las calonnias e el pie de altar e los fornos e las quartas e las fanegas e los molinos e las açennas sean de los comendadores de las casas e los comendadores, del pie de altar, den de comer al clerigo e la soldada dengela del bastimento.

\section{[folio 46v]}

Otrosi, establesçemos que algund omme fidalgo seyendo fidalgo reptado, quisiere resçebir nuestra Orden que non sea ay resçebido fasta que se salue de aquello que es rebtado, e sy a la entrada de la Orden lo negare e despues le fuere probado echenlo fuera de la Orden. Otrosi, que en cada Cabildo General que se fisiere que sean elegidos vesitadores e freyres caualleros e clerigos que bien e fielmente visiten toda la Orden así en lo spiritual conmo en lo tenporal e que fagan emendar lo que iuren, lo que por ellos se pueda e deua emendar; e las traigan al Cabildo General para que por el maestre e por la Orden sean emendadas segund Dios e Orden. Otrosi, que sean puestos procuradores en la corte de Roma e en las 
casas de los reyes tales que bien e fielmente guarden el seruiçio de la Orden; e denle el seruiçio de la Orden, e denles sendas encomiendas e sennales çiertos derechos; en las otras encomiendas den de cada un anno ayan su pension comunal, e seanles pagada e enbiada a çierto tiempo e por onmes del maestre, porque ellos non se partan de las dichas cortes nin del seruiçio de la Orden, e desde que cada uno destos procuradores siruiere cuatro annos, el maestre e la Orden faganle merçed segund sus meresçimientos y pongan y otros asi que trabajo de la Orden se parta comunnalmente entre los freyres.

\section{[folio 47r.]}

Otrosi, que las encomiendas que se den por el maestre e de conseio de los treze e aquellos freyres que se dieren en sus almas que las meresçen mejor e esto sea en Cabildo General e non en otro lugar, e por que los freyres ayan mayor voluntad de reparar las cosas de la Orden que las encomiendas non les sean tomadas sino por sus meresçimientos en Cabildo General e de consejo de los treze e de la mayor parte del Cabildo. Otrosi, que los comendadores de las enfermerias ayan bien e conplidamente todos los derechos que a las encomiendas pertenesçen con las quales prouean los freyres dolientes fisicos e de las otras cosas nesçesarias segund la forma de la Orden conmo en las huestes conmo en todos los otros logares que les menester sea en seruiçio de Dios e de su Orden. Otrosi, que en tiempo que la Orden non oviere guerra con los moros nin el rey llamare a su seruiçio, el maestre traiga consigo diez freyres escuderos de cauallo e treynta onbres de pie e los ofiçiales que menester ovieren de poner de pie e de cauallo. Otrosi, los priores traigan cada uno consigo tres freyres clerigos e tres escuderos de cauallo e dos onmes de pie e de ofiçiales conmo dicho es. Otrosi, que los comendadores mayores cada uno traiga consigo un capellan e quatro freyres de convento e seys escuderos de cauallo e quinze onmes de pie e de ofiçiales conmo dicho es.

\section{[folio 47v.]}

Otrosy, que todos los otros comendadores traygan consigo un freyle morador e dos onmes de cauallo e çinco onmes de pie pero que en el tienpo de la guerra cada uno ha de yr lo mejor aconpannado que pudiere. Otrosí, que los freyres que tienen los castillos fronteros tengan onmes de pie e de cauallo los que menester ovieren e podieren mantener. Pero si algund comendador oviere mas menester de pie que de cauallo para el seruiçio de su Orden, puedanlos traer todavia de liçençia del maestre. Otrosi, en todos los castillos fronteros esten freyres por comendadores e non por alcaydes. Otrosi, que el maestre de a los freyres del convento cauallo e armas quando menester las oviere e para seruiçio de Dios e de su Orden e todas las otras cosas que menester fueren para esto; e que les de otrosi, cada anno para su vestuario a cada uno veinte e quatro varas de valençina o valençin o de arris, e que ayan el dicho vestuario de aqui adelante cada fiesta de Sant Miguel de setiembre e de vestir de su panno cada anno por la dicha fiesta se- 
gund la providençia del maestre. Otrosi, todos los freyres coman con el maestre quanto con el fueren. E non den los bienes de la Orden en conbites nin en vanidades. Pero los comendadores mayores coman en sus posadas, e otros caualleros de liçençia del maestre. Otrosi, que el maestre nin los comendadores mayores non coman en las encomiendas si non una vez en el anno e non mas, ni con mas gente que deuen de tener segund el nuestro ordenamiento. E si vianda a los presentes sobraren, finquen al comendador de la casa.

\section{[folio 48r.]}

Otrosi, que en las cabannas de las yeguas e de las vacas e de las oveias e de los puercos de la Orden ayan comendadores freyres que den buena cuenta e verdadera al maestre e a los treze en el Cabildo General; e los potros que Dios ay diere, que los den a los freyres e non a otro ninguno, e los freyres a quien los dieren que los non den ni vendan, mas crienlos, e sirvan a Dios con ellos e a su Orden; e los nouillos partanlos por las casas de la Orden con que labren e sean dados a los freyres en Cabildo General de cada anno por la fiesta de Todos Santos. Otrosi, que la cama e los pannos que fincaren sean dados a los hospitales de la Orden para el seruiçio de los pobres e todo lo al, finque a la encomienda; afuera los cauallos e las armas de los finados que finquen para los comendadores mayores. Otrosi, que los comendadores mayores no vendan los cauallos ni las armas de los freyres que finaren nin las dar, si dar quisieren, si non a los freyres de la dicha nuestra Orden con que sirvan a Dios e a la dicha Orden; nin los freyres a quien las dieren non las vendan nin las den si non de liçençia de su maestre. Otrosi, que ningund comendador non venda nin de yegua nin vaca nin oveia nin cabra nin puerca, sy no la diere a freyre, o si la diere para la encomienda. Otrosi, que el maestre ni los comendadores mayores non tomen a los otros comendadores las caualgadas ni las aventuras que les acaesçieren en las sus encomiendas; mas que ellos las ayan seyendo juzgadas

\section{[folio 48v.]}

primeramente por los iuezes hordinarios; e si las de otra manera lleuare, pierdanlas los dichos comendadores e ayalas el maestre seyendo juzgadas primeramente asy conmo dicho. Otrosi, que todos los que vinieren de otra tierra a poblar a la tierra de la Orden que sean quitos de pecho por diez annos e por que podria ser, o acaesçer, que el maestre non seria en la tierra e los pobladores non podrían aver sus cartas, tomenlas del comendador de la casa sin chancelleria e valan fasta que ayan las del maestre. Otrosi, si algund comendador tomare algund vasallo de la Orden alguna cosa de lo que oviere sin ge lo mercar paguegelo de la primera rrenta que el dicho vasallo oviere a dar al dicho comendador; e si el dicho comendador non oviere rentas en la encomienda de que paguen, de por lo que conprare al dicho vasallo prenda o dinero, e si asi non fisiere, pague doblado lo que tomo al vasallo e pague una yantar al comendador mayor con la gente que deue traer segund es. Otrosi, que ningund freyre ni pariente nin criado del maestre nin de comendador 
nin de freyres nin de iudio nin de moro, non coja nin recabe los derechos del maestre; mas por mandado del maestre, o de aquellos a quien el diere el poder, cojan dos onbres buenos e raigados que den buena cuenta e verdadera al maestre o a quellos que por el ovieren poder de poner estos cogedores segund dicho es. Aqui acaban los stablesçimientos del maestre don Pelay Peres Correa. 